\title{
The Role of Ulama in Maintaining Religious Tolerance in The Region of South Tangerang and Depok City
}

\author{
Rubiyanah \\ Islamic Communication and Broadcasting Departement \\ Syarif Hidayatullah State Islamic University (UIN) \\ Jakarta, Indonesia. \\ rubiyanah@uinjkt.ac.id
}

\author{
Deden Mauli Darajat \\ Islamic Communication and Broadcasting \\ Departement \\ Syarif Hidayatullah State Islamic University (UIN) \\ Jakarta, Indonesia. \\ kangdedenmd@gmail.com
}

\begin{abstract}
This study aims to reveal the extent to which the role of ulama in maintaining religious tolerance and to contribute to da'wah practitioners, da'wah institutions, and social organizations all aimed at maintaining a harmonious and tolerant religious life to achieve a peaceful life both in the city area Tangerang Selatan and Depok.

This research is a field research based on case study by using qualitative approach which is analytical descriptive in presenting the data. This research is in depth using Sociology and Political approach. Primary data in this research is attitude, gait, activity, and role of ulama $\left(\mathrm{da}^{\prime} \mathrm{i}\right)$ or religious leaders in Tangsel City and Depok City. While the secondary data of this research is the authoritative literature in the form of books and news about religious tolerance issues that exist in Indonesia, especially in the City of Tangsel and Depok.

This research reveals that ulama in South Tangerang and Depok City have not been maximized in performing their role to maintain tolerance among religious people. Therefore this research concludes that ulama should improve the pattern of da'wah, providing opportunities for worship in all flows and religions, and open the dialogue between the people of religion internally and externally. The people of South Tangerang and Depok City expect the ulama should have credibility, can be soothing and protect all circles.
\end{abstract}

Keywords : Role, Ulama, Religious Tolerance, South Tangerang, Depok.

\section{INTRODUCTION}

Religion is one of the most vital dimensions of life in the Unitary State of the Republic of Indonesia, which is illustrated in the ideology of Pancasila, in the first principles "Belief in the one and only God". This is understandable, because the people of Indonesia are so obedient to the teachings of religion. Not only Islam, but also Christian, Catholic, Hindu, Buddhist and Confucian. Such religious beliefs are not problematic, as long as religion and belief are adhered to by conscience, not by resulted in the emergence of a coercive-oriented da'wah practice to gain followers as much as possible. This is clearly contrary to the principle of the Qur'an which forbids the use of coercion in religion (QS. al-Baqarah/2:256) [2].

Based on the latest factual and phenomenon issues that occur in Indonesian society, especially the people of coercion and intimidation [1]. In a sociological context, religious life can be manifested in the form of tolerance or harmony between religious life. In Indonesia, religious harmony is an important part in fostering national unity and entity. In Article 29 paragraph (2) of the 1945 Constitution stated:

"The State guarantees all persons the freedom of worship, each according to his/her own religion of belief".

Referring to the annual report of The Wahid Institute, that during January-December 2013, the number of violations or intolerance of religious beliefs recorded 245 events, they consist of: 106 occurrences (43\%) involved state actors and 139 occurrences $(57 \%)$ of nonstate actors. The total number of violent and intolerant acts reached 280 cases: 121 actions $(43 \%)$ was done by state actors and 159 actions $(57 \%)$ by non-state actors.

Cases of denial of church construction in Bogor and Cinere Depok, burning mosque in Tolikara Papua, the rejection of Shia in Madura, Ahmadiyah in Kuningan West Java and also denial of mosque construction in Manado have added the table of religious intolerance cases in Indonesia. The rejection of Ahok to be the governor of DKI Jakarta which considered by some people as a form of intolerance is the most conspicuous case throughout 20162017.

The role of ulama is very important in responding religious issues. Fatwa ulama as a figure who is considered authoritative in religious matters, may drive to conflicts and confuse the public if it stands in one of the group and make the community provoked. Therefore, the ulama are expected to reduce the unharmonious atmosphere and become the unifier of the ummah.

Redefined about dakwah that is currently still focused on understanding "Invite other people of different religions to convert their beliefs", is indispensable. The impact of a false understanding of the meaning of da'wah.

South Tangerang and Depok, then this research is very important because the conflicts of religion arising from the intolerant attitude of the religious community actually emerged from the ulama who did not take an active role in maintaining the existing tolerance, or even damage it. 


\section{METHODS}

This research is a field research based on case study by using qualitative approach which is analytical descriptive in presenting the data. This research is in depth using Sociology and Political approach. The sociology approach is used in order to map and clarify the thoughts and mindsets of figures and scholars who become the source of data in research. While political approach is used in order to shoot the attitude and even the perception of ulama; to religious tolerance [3]. The attitude of maintaining the tolerance done is influenced by the politics and interests of certain groups in society. In addition, the political approach is used because every norm in the life of society reflects the reality and the desire of the society itself which is then politically contested.

This research makes the Ulama and the community as subject and informant by targeting how effort done by dai or ulama 'in maintaining religious tolerance in Tangerang Selatan and Depok region, with details of 3 of 7 sub districts in Tangsel namely subdistrict, Pamulang, Pondok Aren, and East Ciputat. While the city of Depok 3 of 11 districts of Cinere, Pancoran Mas, and Sawangan. This study was conducted for approximately 5 months, from June to November.

The primary data in this study are the attitudes, gait, activities, and role of ulama (da'i) or religious leaders in Tangsel City and Depok City in establishing the harmony and religious tolerance found in their lecture content, their perception on religious tolerance issues. There are 3 subdistricts from 7 subdistricts in South Tangerang City which become the source of this research data are Pamulang, Pondok Aren, and Ciputat Timur. For Depok city area consisting of 11 subdistricts, and only 3 districts used as data source that is District Cinere, and Sawangan. While the secondary data of this research is the authoritative literature in the form of books and news about religious tolerance issues that exist in Indonesia, especially in Tangsel and Depok City, both from print and online or offline electronic media,.

Referring to the data and data sources above, this study uses observation, interview, and documentation techniques as data collection techniques. Instruments in this study is the researcher himself while the researcher's tool is an interview guide. Technique of examination of data validity by triangulation method, that is checking degree of trust of information in data source) [4], in this case is result of interview between informant one with other informant (da'i, head of religious institution and public figure) technique of data analysis in research this is a qualitative data analysis technique of the domain model, that is classifying data based on location, reason, attribute or characteristic, cause and effect, purpose and function.This technique is used because this research is aimed or explorative with the presentation of descriptive data [5]. This technique is done considering the domain model will further deepen the analysis of the subject and object of research and explore it through descriptive analysis.

\section{RESULT AND DISCUSSION}

The people of South Tangerang City come from various tribes and cultures. The original inhabitants are
Betawi, Sundanese and the rest are urban communities coming from various regions [6].

The population of South Tangerang is based on the religion that is embraced by each society, Islam is 902.282 people, Christian as many as 58,237 people, Catholics 41,185 , Hindus 24,384 people, Buddhist as many as 13,844 people, Confucius as many as 1974 souls and the flow of trust as much 120. Of this number the majority of the population of South Tangerang City embraced Islam as much as $86.59 \%$. During the year 2009 recorded the number of religious facilities in the city of South Tangerang are 497 mosques 1,015 mosques, 40 churches, 3 temples, 6 temples, and 2 temples.

Islamic nuance is more coloring the life of the people of South Tangerang City, this is because the number of Muslims who reached almost 90 percent, so harmony between religions so far, do not become obstacles. This can be seen in the calm and peaceful coexistence conditions that have existed all along. Therefore it is necessary an effort to maintain religious tolerance that has been going well to avoid the mains and attitudes that can damage the harmonious life among followers of religion that has lasted long in the region.

Not too different from South Tangerang, the population of Depok City based on religion that embraced Islam is as many as 1. 853.898, Christian 105. 218, Catholics 35,401, Hindus counted 40,001, Buddhist as much as 6. 718, Confucius 2,255 and others till 120 people. Of this number the majority of the population of Depok embraced Islam as much as 91, 16\%. During the year 2014 recorded the number of religious facilities in several religious services in the city of Depok as much as Mosque 4.216, Mushola 1,406, Church 132, Pura 5, and

Vihara 2 [7].

Depok City Government has a determination to protect, provide security and peace both in and out for the community, and maintain the physical and mental resilience of the people of Depok in facing all kinds of disturbances, obstacles and challenges that come from anywhere to the life of the Nation and the Republic of Indonesia based on Pancasila.

The results and discussion of this research refers to the research question in this research is How is the efforts of scholars in maintaining religious tolerance? and How does society expect the role of ulama in maintaining religious tolerance in Tangerang Selatan and Depok?

So, referring to the results of data collection and analysis, it can be revealed that the role of ulama in maintaining religious tolerance can be sought and achieved in the following ways: 1 . Improving the Pattern of Dakwah

In an effort to maintain religious tolerance, da'i as religiouse figure should pay attention to the goals, materials, and media used in preaching. Da'wah that is done by da'i must be embracing, in the sense of protect whole society regardless of tribe, religion and race. There should be no discrimination or cornering other groups outside the group or outside of Islam. Da'i or ulama should convey Islam as Rahmatan Lil Alamin (grace for the whole of nature). All da'wah material should refer to the main source, namely al-Qur'an and al-Sunnah that are contextualized on contemporary factual issues. 
Some ulama who represent the area of South Tangerang city agreed that maintaining religious harmony is an important part in da'wah activities. Thus, da'wah should make a positive contribution to the community in instilling tolerance among religious people. The role of ulama and da'i is to determine the style of propagation received by the ummah, whether the propaganda should impose the will of people of different beliefs to convert their religion, or to wisely carry the teachings of religion according to the guidance of the Qur'an and Sunnah without imposing the will against mad 'u (the object of dakwah) among Muslims and non-Muslims.

Ulama is like a lamp that must be present in the community to illuminate life. Objects that are illuminated are of course heterogeneous: religion, ethnicity and race. Because of this condition, ulama should choose a suitable theme and not offensive related to some tribe, religion, race, and among groups when delivering da'wah in the presence of a heterogeneous audience. Reflecting on the da'wah done by the Messenger of Allah, the thing worth noting is the accuracy of the Prophet in fostering and glueing the cells of society. Starting from the people closest, then the longer the more spacious. Between the group muhajirin (Mecca) and Ansar in Medina, glued by the Prophet by binding some 'key person' each group became brothers. Even among the large groups of Muslims with Jewish groups are also glued together in order to maintain the integrity and resilience of the city of Medina. Emphasized in the $44^{\text {th }}$ Medina Charter point: "All citizens will be cooperate in the face of other parties who launch attacks against Yathrib".

Likewise with the media, da'wah also follow the rapid development of the message and the use of media, especially social media (medsos). Some ulama use this as a means to convey da'wah. In order that the presence of medsos is not only validly methodological, the da'wah is required to be served as something of a fine meal that always tastes and invites the tastes of every person it faces. Indirectly, the object of da'wah in medsos comes from various backgrounds, not close the possibility of nonMuslims. Therefore, the material presented is also diverse, so that da'wah can be right on target.

2. Providing Worship Opportunity to All Flow and Religion

In Sawangan District, Depok City, Government and society provide opportunities to worship any adherents of any religion, even if they are a minority. However, tolerance does not mean free to act as if there is no rule, because there are principles that must be held and led. Therefore, despite upholding the values of tolerance, but when the case of the establishment of houses of worship without procedures in accordance with the provisions and rules of government, then it can not be justified [8].

The case of Muslim rallies over objections to church construction in the Pasir Putih area of Depok, is the impact of the problem of permitting the establishment of places of worship. In addition to the problem of church construction permits, intolerance cases also often occur due to clogging of inter-religious dialogue. The event of mass mobilization in the wake of the Ahmadiyah issue in Sawangan, is one of the evidences of effective communication from the parties concerned. Here the role of ulama is very urgent to pioneer in the forefront as mediator of the ummah. The presence of government is also very necessary, because it has the policy authority that can set the direction and foothold in the life of society, nation and state.

About the case of the denial of church construction, KH.Mahfudz Anwar who is a member of the Inter-religious Harmony Forum or Forum Kerukunan Umat Beragama (FKUB) Depok, responded quite seriously. He said if there is a proposal for church construction in Depok City area, usually ask for recommendation from FKUB Depok. For example, the construction of the church will be built in a predominantly Christian area and there are already signatures from the surrounding population, so it is not a problem. However, if the majority of the population is Muslim, as in Beji, then FKUB does not approve it, because it is not in accordance with the rules in force.

If in Depok City, some religious personage still seem ambiguous in addressing the provision of worship services for certain streams within Islam (eg Ahmadiyah case), and also for non-Muslims, the description of this matter was responded to slightly differently by the Chairman of the Indonesian Ulama Council (MUI) South Tangerang, K.H. Muhammad Saidi. According to him, worship in accordance with the flow and belief that is the right of each adherent of religion, so should not be hindered. Because Indonesia is a state based on Pancasila, not a state based on one religion. As an ulama and da'i, Kyai Saidi always emphasized the importance of freedom of religion, not a single religion although the majority (like Islam) suppressed other people and prevented them from worshiping, including building houses of worship as long as they did not violate the rules set by the government.

3. Opening the Dialogue between the People of Religion internally and externally

The meeting of interfaith figures in Depok City is often held by FKUB. Besides being one of the program of FKUB, the meeting is also a place of hospitality of interfaith personages. In the context of dialogue, KH. Zainuddin Anwar, one of the charismatic ulama of Depok City, was present as a pioneer of interfaith dialogue. Even Kyai who had been a caretaker of Pondok Pesantren (boarding school) Al-Hamidiyah Depok, often visited by pastors and other religious leaders in his house adjacent to the boarding school.

The dialogue between religious people should be used as a forum for religious harmony that can bridge various problems arising from religious issues in the community. From here the dialogue not only serves to seek agreement, but also the control of activities that are considered destructive relationship of religious life.

The existence of dialogue is very important as an effort to avoid the attitude of religious intolerance. Therefore, dialogue must only be done between religions, but also between madhhab of religion. In this regard, internal and external-religious dialogue must be conducted intensively and continuously, in order to avoid intolerance in society. In reality, making internal-religious dialogue is more difficult than external. Indonesian Ulama Council (MUI) Pamulang South Tangerang City regularly holds regular meetings that invite representatives of $\mathrm{NU}$, Muhammadiyah, and the flow of Abu Jibril. This is done in order to minimize the occurrence of internal-religious conflict. Kyai Saidi as general chairman of MUI South Tangerang City admitted shame, if there is a conflict that 
occurs due to religious issues, especially still in one religion.

Based on the results of interviews with some religious personages, all parties involved in the dialogue forum should be aware that there are areas of confidence that are difficult to reconcile, so coercion of people with different beliefs is not only difficult, but also produces tension, cracked relationships that hinder the process of dialogue. So the most appropriate step in building togetherness among religious people is to discuss at the same time looking for effective solutions to a number of trends considered harm harmony of religious life.

From the results of existing analysis, it is also found that until now the role of ulama in maintaining religious tolerance in South Tangerang and Depok City is still far from ideal. It is also evident from the data and results of interviews with the community that they still hope ulama can be the front guard in maintaining religious tolerance even inter-religious. The following is the public's expectation of the ulama.

\section{A. Ulama Must Have Credibility}

Ulama is a collection of people who have knowledge in the field of sharia sciences: fiqh, tafseer, hadith, monotheism, kalam, akhlak, tasawuf, and so forth a status of a Muslim. Therefore, someone who is knowledgeable in Islam but not a Muslim, then his status is not an ulama, but a scientist. Ulama is a person who has a qualified knowledge, so bring himself has the nature khasyyah (fear) only to Allah SWT alone. In the hadith mentioned, that ulama are the heirs of the prophets (al'ulama waratsat alanbiya ').

In addition to the abilities mentioned above, nowadays, an ulama must hold and follow the development of technology, so he is clever as well as looking at any information that develops. An ulama is required to understand the development of his society. In the modern world today, an ulama cannot simply explore the sciences of jurisprudence, tafsir or hadith only, especially if his knowledge is only a static memorization.

To address the challenges and problems of the present and the future, it is necessary to overcome the full and dynamic sciences of Islam, in addition to the tools of science and insight that can be used to understand the development of society. Thus, ulama can always provide guidance and direction that is acceptable, not left behind or trapped by a static religious understanding and narrow insight.

\section{B. Ulama Must Sooting and Protect All Circles}

Today, many issues are related to ulama who like to obey. Even this happens because the ulama as a figure who should be able to muffle the atmosphere, so the community provoked. For example, issues related to the election of governor of DKI Jakarta, Ahok. Many of the issues are not clear sources and correctness are deliberately made to divide the community.

One of the people of Depok City expresses his criticism and hope towards the ulama, there is a fiery ulama in expressing opinions, but the contents are very provocative and lack of knowledge. Ulama should have broad, moderate, open-minded insight, and not easily carried over issues. Moreover, it leads to issues related to tribe, custom, Race, and Religion (SARA).

The opinion of the residents of Depok above is not different from a citizen domiciled in South Tangerang City, who hopes that people can feel the peace after listening to the ulama's advice, not the other way. An ulama must also be firm, not loud in saying and advising As explicitly stated here, the community feels a clear footing in terms of legal certainty concerning the fatwa which the ulama conveys.

In this case, the ulama should be the unifying of the ummah, that it is necessary for its role in fostering and guiding the followers of the heretical flows back to the right path, mediating (peace) between conflicting parties and disputes among the Ummah, so that disputes and divisions can be avoided or minimized.

\section{ACKNOWLEDGMENT}

The role of ulama in addressing religious issues is being important. If the fatwa confuses the people, even tends to cause conflict, it can make people provoked. This occurs because the role of the ulama as a figure that is considered capable of reducing the atmosphere and become unifying people. Among the ulama's role in maintaining inter-religious tolerance, based on interviews from several in the South Tangerang and Depok areas are the ulama must improve the pattern of da'wah, the ulama must provide opportunities for worship in all flows and religions, and the ulama must open the dialogue between the people of religion internally and externally. While public expectations of the role of ulama are the ulama must have credibility and he must protect all people and all circles.

\section{REFERENCES}

[1] Siradj, Said Aqil and Haerudin, Mamang Muhamad, Berkah Islam

Indonesia: Jalan Dakwah Rahmatan Lil 'alamin. Jakarta: PT Elex Media Komputindo, 2015.

[2] Al-Quran al-Karim

[3] Fisher, Rob, "Philosophical Approach", in Peter Connolly, Approaches to The Study of Religion. London: Cassel, 1999.

[4] Bungin, Burhan, Penelitian Kualitatif. Jakarta: Kencana, 2011.

[5] Bungin, Burhan, Analisis Data Penelitian Kualitatif. Jakarta: PT. Raja Grafindo Persada, 2012.

[6] Tangsel, "Profil Kota Tangsel", dalam

http://www.kemendagri.go.id/pages/profildaerah/kabupaten/id/3 6/name/banten/detail/3674/kotatangerang-selatan, accessed on 8 October 2017.

[7] Badan Pusat Statistik Kota Depok, Kota Depok dalam Angka 2013/2014. Depok: BPS Kota Depok, 214. in

http://fpksdepok.org/wp-content/uploads/2015/06/DDA20132014.pdf, downloaded and accessed on 1 October 2017.

[8] Regulation of the Minister of Religious Affairs and Minister of Home Affairs. No. 9 of 2006 and No. 8 of 2006 on Guidelines for Implementation of Duties of Regional Head / Deputy Head of Region in Maintaining Religious Harmony, Empowerment of Religious Harmony Forum, and Establishment of houses of worship, in

http://www.hukumonline.com/klinik/detail/lt57f306314feb9/the -based-home-history requirements, accessed on 10 October 2017. 